\title{
Geta vísindin klukkað samfélagið?
}

Tilfærsla á klukkunni hefur lengi verið til umræðu á Íslandi og tillögur um að laga hana að landfræðilegri stöðu Íslands oft komið til tals. Рað parf ekki að koma á óvart par sem hér er ýmist of lengi dimmt eða albjart marga mánuði á ári. Nýlega skipaði ráðherra starfshóp um petta málefni og var skýrsla starfshópsins góð og ítarleg um kosti breyttrar klukku. Hins vegar var mjög lítið fjallað um neikvæð áhrif breytingarinnar og var par til dæmis enginn fulltrúi frá ípróttahreyfingunni sem hefur ítrekað gert athugasemdir við fyrri frumvörp er varða breytingu á klukkunni. Framsetning starfshóps ráðherra var einhliða og mikið gert úr kostum klukkubreytingar en lítið úr göllum. Dæmi um petta er yfirlitstafla par sem bornir eru saman kostir og gallar valkostanna sem nefndin leggur fram. Sú leið sem nefndin leggur til er sett fram á litríkum grunni en hinar leiðirnar í gráu. Par er talað um að klukkubreyting geti lagað of stuttan svefn og í mörgum atriðum hvaða breytingar gætu orðið ef svefn pjóðarinnar lengist. Hins vegar er aðeins nefnt í einu atriði að minna dagsljós gæti minnkað hreyfingu en ekkert um hvaða afleiðingar pað hefur.

Með fækkun bjartra stunda að afloknum skóla- og vinnudegi má til dæmis telja líklegt að hreyfing ungmenna minnki. Hún er nú pegar í harðri samkeppni við aðra afpreyingu en engin áhersla var á petta atriði í skýrslunni og ekki heldur í umfjöllun fjölmiðla. Pó eru til rannsóknir sem benda til slíkra áhrifa. Má nefna samantektarrannsókn úr stórum gagnagrunni hreyfimæla í 9 löndum par sem niðurstaðan er að aukin dagsbirta í formi sumartíma sé líkleg til að auka hreyfingu ungmenna ${ }^{1}$ og nýlega innlenda rannsókn, sem skýrsluhöfundar áðurnefnds starfshóps vitnuðu til varðandi svefninn, par sem tengsl fundust milli dagsbirtu og hreyfingar unglinga hér á landi, sérstaklega stúlkna. ${ }^{2}$

Раð sem svo gerist í kjölfarið er að pessi einhliða framsetning litar fjölmiðlaumræðuna. Рað var ekki annað að heyra af umræðunni en að svefnvandi unglinga væri auðleyst mál með klukkubreytingu og í raun val um hvort við fræddum pjóðina um mikilvægi svefnsins eða bara einfaldlega breyttum klukkunni og pá væri sá vandi úr sögunni. Að pað væri bara fínt að leysa of stuttan svefn hjá heilli pjóð svona. Fulltrúarnir í ráðgjafahópi ráðherra hafa sýnt með sínum fyrri skrifum að peir gera sér grein fyrir að of stuttur svefn er flóknara vandamál en svo, en fjölmiðlaumræðan var á pennan veg.
Samráđsgátt stjórnvalda er enn eitt framfaraskrefið í átt að virkari pátttöku landsmanna til stuðnings ákvarðanatöku stjórnvalda. Til að hún nýtist sem skyldi er mikilvægt að strax í upphaflegri kynningu mála séu með hlutlausum hætti kynntir kostir og gallar breytinga sem fyrirhugaðar eru. Pannig átta lesendur sig á að stjórnvöld hafi vegið og metið bæði kosti og galla breytinga og í kjölfarið lagt til pá breytingu sem á að gera. Pannig myndast traust á að ákvörðunin sé rétt, umræðan á eftir verður markvissari og styður betur við ákvarðanaferlið.

Samfélög og breytingar á peim geta valdið vanda og bætt úr vanda er varða lýðheilsu íbúanna. Mitt sérsvið, offita barna, er eitt skýrasta dæmið um pað. Breytt samfélagsmynstur víða í hinum vestræna heimi hefur margfaldað offitu í öllum aldurshópum með pekktum afleiðingum fyrir heilsuna. Margir sem sinna pessum málaflokki hafa pví kallað eftir breytingum en oft hefur reynst erfitt að sannfæra ráðamenn um mikilvægið.

Í góðu og opnu samfélagi sem breytist jafn hratt og okkar, par sem upplýsingar berast hratt á milli manna, eiga upplýsingar sem byggjast á vísindalegum rannsóknum undir högg að sækja. Pær verða til á lengri tíma og erfitt getur verið að láta pær berast pangað sem pörf er á. Læknablaðið hefur að undanförnu blandað sér í vísindalega umræðu um ýmis mál í samfélaginu og er pað vel. Pannig getur gagnrýnið vísindarit átt pátt í að efla vísindalega umræðu um pær breytingar sem gera parf til að bæta samfélagið okkar enn frekar.

Á hvorn veginn sem ákvörðunin fellur er mikilvægt að fylgst verði með afleiðingunum og að yfirvöld setji sér mælikvarða á hvort sá árangur næst sem að er stefnt. Ekki er síður mikilvægt að mæla hverju er kostað til að sá árangur náist. Annars erum við meira í skollaleik par sem samfélagið er með bundið fyrir augun. Best er pegar vísindin og samfélagið eru í markvissum eltingaleik og skiptast á að ver'ann pegar annað nær að klukka hitt.

\section{Heimildir}

1. Goodman A, Page AS, Cooper AR, and for the International Children's Accelerometry Database (ICAD) Collaborators. Daylight saving time as a potential public health intervention: an observational study of evening daylight and objectively-measured physical activity among 23,000 children from 9 countries. Int J Behav Nutr Phys Act 2014; 11: 84.

2. Rögnvaldsdóttir V, Valdimarsdóttir BM, Brychta R, Hrafnkelsdóttir SM, Arngrímsson SÁ, Jóhannsson E. Hreyfing og svefn reykvískra ungmenna. Læknablaðið 2018; 104: 79-85.

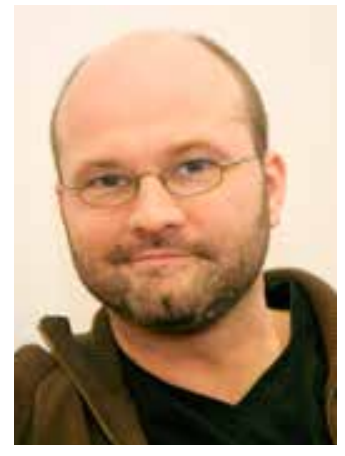

Tryggvi Helgason

barnalæknir

Heilsuskóla

Barnaspítalans og

Domus Medica.

tryggvih@mac.com

\section{Can science catch the tail of society?}

Tryggvi Helgason MD Pediatrician Childrens Hospital, obesity team and general pediatrician 